\title{
BRAND TRUST AND BRAND AFFECT: THEIR STRATEGIC IMPORTANCE ON BRAND LOYALTY
}

\author{
Ebru Tümer KABADAYI \\ Alev KOÇAK ALAN \\ Gebze Institute of Technology, Turkey
}

\begin{abstract}
This paper elucidates the relevance of brand trust on consumer behavior and marketing management, particularly in retail management. The purpose of this research is to investigate the effects of factors on consumers' brand loyalty in service setting. According to purpose, the study empirically tests a model which proposed that brand trust and consumers' brand affect have influence on consumers' brand loyalty. The researchers administer a survey to 98 consumers. Using these data, the researchers test the hypothesis and model with structural equation modeling. The results indicate these factors have an effect on consumers' brand loyalty. In addition the findings confirm the indirect effect of consumers' brand affect on brand trust and consumers' brand loyalty relationship. Managerial implications and future research directions are also discussed.
\end{abstract}

Keywords: Brand loyalty, Brand Trust, Brand Affect, Retailing, Structural Equation Modeling

\section{INTRODUCTION}

In a growing competences environment; brand becomes most valuable, strategic and critical assets of a company and receives considerable attention (Martin et al., 2005). Brand is one of the main tools for marketers to alleviate consumers' price sensitivity in market competition (Helmig et al.,2007). Consumers are prone to pay more for a brand, because they perceive an excellent value in the brand that no competitor can provide (Jacoby \& Chestnut, 1978). Therefore brand managers attempt to tackle this issue by generating stronger brands (Keller, 1993). A common strategy used to strengthen a brand is creating brand trust between company and consumer. Brand trust provides a superior lens through which to examine and assess consumers' behavioral responses.

Similarly, consumers' brand affect plays a significant role between company and consumer relationship. Relationship is built on the foundation of brand affect (Berry \& Parasuraman, 1991) and brand affect causes consumers' brand loyalty which is initially viewed as consumers' repurchase intention (Morgan \& Hunt, 1994).

Brand affect and brand trust behave like the main key factors for firm success. From marketers' point of view, brand affect and brand trust work as a preserver of relationship investment for companies' partner; provide long term benefits; prevent high risk actions (Morgan \& Hunt, 1994) and they are the cornerstone of strategic partnership (Spekman, 1988). From consumers' point of view, they are essential assets for consumer company relationship and they are main reasons underlying consumers' behavioral responses towards companies (Caceres \& Paparoidamis, 2007) Berry and Parasuraman (1991) affirm that effective service marketing depends on successful management of both brand affect and brand trust.

Many studies concentrate on role of brand trust and brand affect from company-supplier relationship (Chiou \& Droge, 2006; Tümer et al., 2011). But studies are scarce that fully investigate brand trust and brand affect, especially brand affect, from company- consumer relationship in one integrated framework. To fill this research gap, the present study objective is to focus on two topics; (1) How brand trust and brand affect influence consumers' brand loyalty? and (2) Does brand affect mediate the relationship between brand trust and consumers' brand loyalty? This study builds on and contributes to previous literature by examining this constructs from company- consumer point of view. 
We first review the relevant literature and establish a conceptual framework. On this basis, research hypothesis are formulated. Next we specify the methodology in detail and present the findings. Then we draw theoretical as well as managerial implications. Finally, we recognize the limitations of this study and suggest future research directions.

\section{CONCEPTIONAL FRAMEWORK}

Our conceptual model is developed and demonstrated in Fig.1. The model shows that consumer's brand loyalty toward a store is influenced by the consumer's brand trust and brand affect. Additionally, brand trust has an indirect effect on brand loyalty through brand affect. The model posits brand affect as critical mediators of the impact of brand loyalty. We review the key constructs of our conceptual framework and define the theoretical background supporting the relationships contained therein.

\section{Figure 1. Conceptual Model}

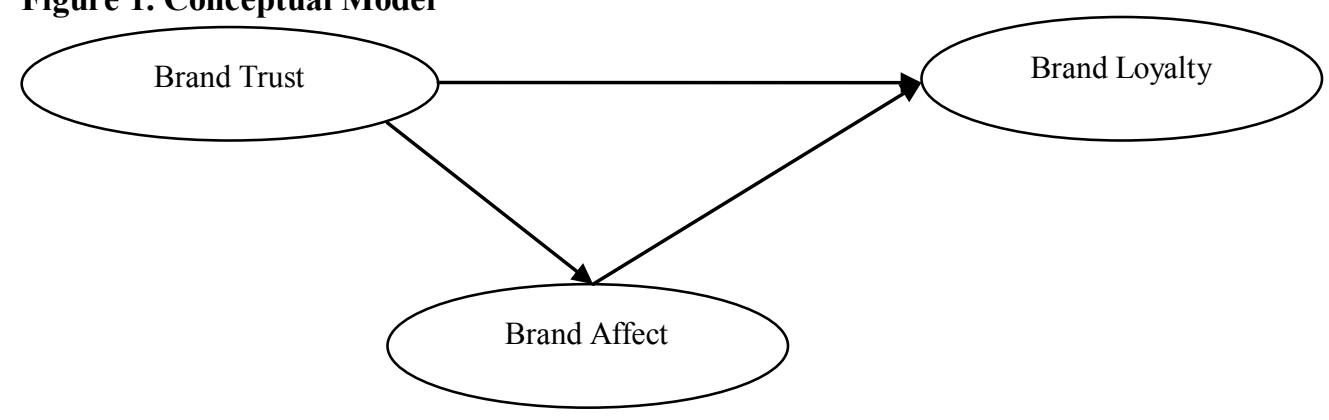

\section{Brand Trust}

Brand trust is viewed as central in many studies (Doney \& Cannon, 1997; Moorman et al., 1992). It is conceptualized as a notable factor in the firm success (Morgan \& Hunt, 1994). Chaudhuri and Holbrook (2001) define brand trust as "the willingness of the average consumer to rely on the ability of the brand to perform its stated function". Brand trust arises after consumers' evaluation of companies' offerings. If companies provide beliefs of safety, honesty and reliability about their brands to consumers, brand trust will be generated subsequently (Doney \& Cannon, 1997). It can be interpreted that brand trust is created and developed by direct experiences of consumer via brands.

The main difference between brand trust and brand affect is; brand trust is viewed as a long process which can be occurred by thought and consideration of consumer experiences about store while brand affect is consisted of impulsive feelings which can be formed, spontaneously (Chaudhuri \& Holbrook, 2001). Therefore brand trust can be discussed as a cognitive component (Casalo et al., 2007) which may induce emotional response, namely brand affect.

On the other hand, brand trust leads brand loyalty (Delgado-Ballester \& Munuera-Alemán, 2001). It is due to brand trust's ability for creating highly valued relationship (Chaudhuri \& Holbrook, 2002). It shows that brand loyalty is part of the continual process of valuable and notable relationship which is produced by brand trust. Moreover literature shows support that brand trust is a determinant of loyalty Wu et al., 2008; Berry, 1983). Based on the literature review, we suggest the following hypothesis;

\section{H1: Brand trust has positive effect on consumers' brand affect}

H2: Brand trust has positive effect on consumers' brand loyalty

\section{Brand Affect}

Brand trust and brand affect are closely related dimensions. Like brand trust, brand affect is also studied widely in marketing literature (Iglesias et al., 2011). Chaudhuri and Holbrook (2001) define brand affect as "brand's potential to elicit a positive emotional response in the average consumer as a result of its use". In other words it can be described as consumers' emotional response towards a brand in consequence of having an experience with the brand. Therefore we suggest that brand affect occurs under favor of close relationship with brand. Likewise, literature suggests that favorable and positive 
emotions are associated with high level of brand loyalty (Chaudhuri \& Holbrook, 2002). It is showed that brand loyalty is greater under the condition of positive emotional affect that prompt consumers to enhance positive attitudes towards a brand (Dick \& Basu, 2004). Many studies are empirically evident for brand affect has a significant role to create brand loyalty (Chaudhuri \& Holbrook, 2002; Sung $\& \mathrm{Kim}, 2010)$. In line with this discussion we propose the following hypotheses.

\section{H3: Consumers' brand affect has positive effect on consumers' brand loyalty}

\section{RESEARCH METHOD}

The data used for the current study were collected from graduate and undergraduate students from a university, located in Kocaeli. The questionnaire contained 14 questions divided into three parts to conduct to certify the reliability of the scales, and some modifications were made based on feedbacks. The data collection was carried out for two weeks at October. The survey was conducted on consumers who have experience in the coffee store. The reasons for choosing coffee store are; they are the main actors of service industries and they are more distinctive places to evaluate both brand affect and brand trust of consumers. Participants were asked to answer questions in consideration of the coffee store where they had visited lastly. The reason for choosing coffee store, they are very convenient places to capture brand affect of consumers. Convenience sampling technique was used to select the participants. Consequentially 98 respondents were emerged.

The demographic characteristics of the sample are presented in Table1. Respondents consisted of $52 \%$ male and $48 \%$ female. In terms of age, $44.9 \%$ of the respondents were between 20-30 years old and $55.1 \%$ were between $30-40$ years old. Most of the respondents (48\%) visited the coffee store s more than2-3 times per month. Moreover the majority of the respondents (37.8\%) had 500-1500€ monthly income.

\section{Table 1- Demographic Characteristics of Sample (n=98)}

\begin{tabular}{llll}
\hline Characteristics & & $n$ & $\%$ \\
\hline Gender & Male & 51 & $52,0 \%$ \\
& Female & 47 & $48,0 \%$ \\
Age & $20-30$ & 44 & $44,9 \%$ \\
\multirow{3}{*}{ Educational level } & $30-40$ & 54 & $55,1 \%$ \\
\multirow{2}{*}{ Visiting frequency in a month } & University & 47 & $48,0 \%$ \\
& Graduate school & 51 & $52,0 \%$ \\
\multirow{2}{*}{ Monthly income } & 1 & 36 & $36,7 \%$ \\
& $2-3$ & 47 & $48,0 \%$ \\
& $4-$ & 15 & $15,3 \%$ \\
& Less than $500 €$ & 5 & $5,1 \%$ \\
& $500-1500 €$ & 37 & $37,8 \%$ \\
& $1500-2500 €$ & 23 & $23,5 \%$ \\
& $2500-3500 €$ & 18 & $18,4 \%$ \\
& More than $3500 €$ & 15 & $15,3 \%$ \\
\hline
\end{tabular}

\section{Measurement}

To measure all constructs, we use five-point Likert type scales with anchors 1-strongly disagree and 5strongly agree. Our measure of brand trust is summarized from Lau and Lee (1999) study and includes four items. We use seven items to measure brand affect Izard, 1977; Mano \& Oliver, 1993; Richins, 1997). Brand loyalty is measured by three items (Lau \& Lee, 1999, Zeithaml et al., 1996) The measurement items are presented in Appendix A.

\section{Validity and Reliability of Measures}

This study first conducted a confirmatory factor analysis (CFA), as a first step of Anderson Gerbing two steps approach, with a maximum likelihood to estimate the measurement model by verifying the 
underlying structure of constructs. This study also checked unidimensionality, reliabilities, and validities of the three-factor measurement model before testing the structural model which is contained of brand trust, brand affect and brand loyalty. Based on the CFA results, we analyze composite reliability, convergent validity and discriminant validity of all the constructs, following the guideline from previous research (Zeithaml et al., 1996; Anderson \& Gerbing, 1988; Fornell \& Larcker, 1981). The composite reliability scores (CR) are ranging from 0.78 to 0.88 and alpha's coefficients are ranging from 0.77 to 0.87 (Fornell \& Larcker, 1981). They are all above the recommended cut off of 0.60 (Anderson \& Gerbing, 1988) are considered acceptable. The evidence of the convergent validity of the measures is all confirmatory factor loadings around 0.70 and was significant at the alpha level of 0.001 ( Zeithaml et al., 1996). Discriminant validity is calculated via Ave results, ranging from 0.50 to 0.64. AVE results are greater than squared correlations which indicate unidimensionality and suggest that the three-factors are distinct to each other (Anderson \& Gerbing, 1988). Discriminant validity indicates that a construct does not significantly share information with the other construct. All measures of the model are reliable and valid overall. That is, the three-factor confirmatory measurement model demonstrated the soundness of its measurement properties. The $\chi^{2}$ value with 61 degrees of freedom was $81.30(p<0.001)$. Given the known sensitivity of the $\chi^{2}$ statistics test to sample size, several widely used goodness-of-fit indices demonstrated that the confirmatory factor model fit the data well $(\chi 2 / \mathrm{df}=1.33, \mathrm{NFI}=0.87, \mathrm{CFI}=0.96, \mathrm{IFI}=0.96, \mathrm{RMSEA}=0.06)$. All statistics support the overall, satisfactory measurement quality given by the number of indicators.

Table3 shows the intercorrelations between three construct in this study. As indicated in Table 3; an assessment of the bivariate correlations present that the dimensions and items used to measure brand trust is positively related with brand affect and brand loyalty, additionally positive relationship between brand affect and Brand loyalty is observed.

Table 2- Measurement Items and Reliability and Values

\begin{tabular}{|c|c|c|c|c|}
\hline Construct & Standardized loadings & $\begin{array}{l}\text { Cronbach's } \\
\text { pha }\end{array}$ & $\begin{array}{ll}\text { Al- } & \\
& \text { CCR }\end{array}$ & AVE \\
\hline Brand Trust & & .867 & .877 & .642 \\
\hline Bt1 & $.78 * *$ & & & \\
\hline Bt2 & $.85^{* *}$ & & & \\
\hline $\mathrm{Bt} 3$ & $.88 * *$ & & & \\
\hline Bt4 & $.68 * *$ & & & \\
\hline Brand affect & & .847 & .858 & .503 \\
\hline Ba1 & $.71 * *$ & & & \\
\hline $\mathrm{Ba} 2$ & $.74 * *$ & & & \\
\hline $\mathrm{Ba} 3$ & $.76^{* *}$ & & & \\
\hline $\mathrm{Ba} 4$ & $.65^{* *}$ & & & \\
\hline $\mathrm{Ba} 5$ & $.72 * *$ & & & \\
\hline $\mathrm{Ba} 6$ & $.67 * *$ & & & \\
\hline Brand loyalty & & .773 & .778 & .539 \\
\hline Bl1 & $.69^{* *}$ & & & \\
\hline $\mathrm{B} 12$ & $.74 * *$ & & & \\
\hline $\mathrm{B} 13$ & $.77 * *$ & & & \\
\hline
\end{tabular}

Note: CCR: composite construct reliability. $\chi^{2}=81,30(\mathrm{df}=61), \mathrm{p}<0.001 ; \chi^{2} / \mathrm{df}=1.33$; Root mean squares error approximation $(\mathrm{RMSEA})=0.06$; comparative fit index $(\mathrm{CFI})=0.96$; goodness of fit index $(\mathrm{GFI})=0.89$, adjusted goodness of fit index $(\mathrm{AGFI})$ $=0.84$ and incremental fit index $(\mathrm{IFI})=0,96, * * \mathrm{p}<0.001$.

Table 3- Correlations Estimates

\begin{tabular}{llllll}
\hline & Mean & Std Deviation & $\mathbf{1}$ & $\mathbf{2}$ & $\mathbf{3}$ \\
\hline 1-Brand Trust & 3.85 & 0.60 & 1.00 & & \\
2-Brand affect & 3.54 & 0.73 & $.34(* *)$ & & \\
3-Brand loyalty & 3.92 & 0.63 & $.45(* *)$ & $.47(* *)$ & 1.00 \\
\hline
\end{tabular}

Note: ${ }^{*}$ Correlation is significant at $\mathrm{p}<0.001$ (2-tailed). 


\section{ANALYSES AND RESULTS}

As the next step structural equation modeling is conducted to test the hypotheses. Fig.2 presents the estimated research model, exhibiting the direction and magnitude of proposed effects.

Figure 2. Structural Equation Model with Parameter Estimates

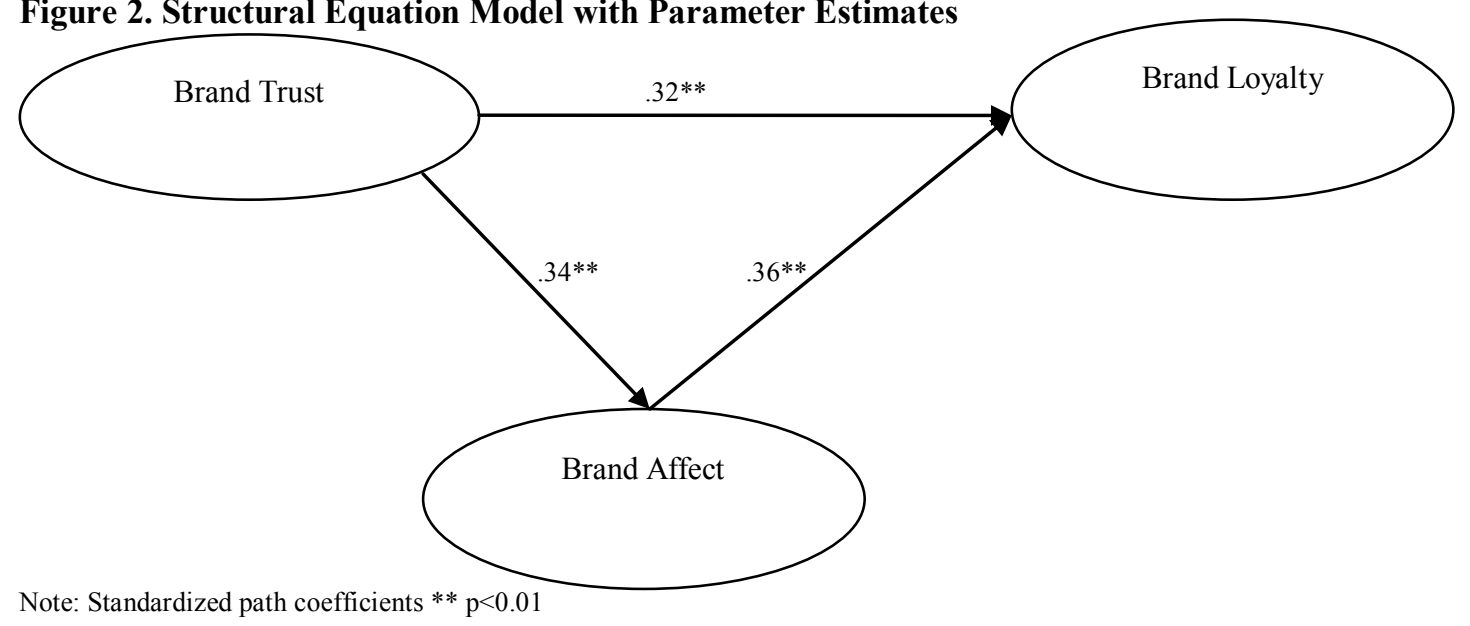

Analysis of structural model yields good fit statistics: $\chi_{(61)}^{2}(\mathrm{p}<.001), \chi^{2} / d f=1.33, \mathrm{CFI}=0.96, \mathrm{IFI}=0.96$, $\mathrm{GFI}=0.89$, RMSEA $=0.06$. The model fit the data well and goodness- of-fit indices are deemed satisfactory; thus, it provides a good basis for testing the hypothesized paths. The parameter estimates of the structural model presents the direct effects of one construct on each other. To examine how brand trust affects consumer's brand affect, Hypothesis 1 is verified and, as a result, accepted $(\beta=.34$; $\mathrm{t}=2.86 ; \mathrm{p}<.01)$. Hypothesis 2 , which hypothesizes a positive relationship between brand trust and brand loyalty, is supported $(\beta=.32 ; \mathrm{t}=2.61 ; \mathrm{p}<.01)$. Hypothesis 3 , which predicts effects of brand affect on brand loyalty, is supported $(\beta=.36 ; \mathrm{t}=2.79 ; \mathrm{p}<.01)$. All of these findings show great support to our hypothesis. They are represented in Table4.

\section{Table 4- Structural Parameter Estimates}

\begin{tabular}{llll}
\hline Hypothesized path & Standardized estimates & t-value & Results \\
\hline H1: Brand Trust $\rightarrow$ Brand Affect & .34 & $2.86^{* *}$ & Supported \\
H2: Brand Trust $\rightarrow$ Brand Loyalty & .32 & $2.61^{* *}$ & Supported \\
H3: Brand Affect $\rightarrow$ Brand Loyalty & .36 & $2.79^{* *}$ & Supported \\
\hline
\end{tabular}

Note: $* * \mathrm{p}<0.01$

\section{Evaluating direct and indirect effects}

Direct, indirect and total effects of the constructs on each other can be evaluated through structural equation modeling. Based on this point, direct and indirect partial influences of brand trust and on brand loyalty are discussed. The results are presented in Table 5 . The findings demonstrate that brand trust have direct and indirect impact on brand loyalty. The indirect effects of constructs clearly expose that brand trust produce more favorable brand loyalty through brand affect. It means that brand affect is partially mediate the relationship between brand trust and brand loyalty. Additionally; the square multiple correlation shows that a very considerable portion of variance in brand loyalty is explained by the depicted relationships (\%31). 


\begin{tabular}{lll}
\hline & Brand Trust & Brand Affect \\
\hline Total Effect & & \\
Brand Affect & $.34^{* *}$ & - \\
Brand Loyalty & $.45^{* *}$ & $.36^{* *}$ \\
Direct Effect & & \\
Brand Loyalty & $.32^{* *}$ & $.36^{* *}$ \\
Indirect Effect & & - \\
Brand Loyalty & $.12^{* *}$ & - \\
\hline
\end{tabular}

Note: $* * \mathrm{p}<0.01$

\section{CONCLUSION AND RECOMMENDATIONS}

Today a great majority of scholars, companies and consumers have noticed the power and importance of brands. From consumers' point of view, brands have moved to the center of consumers' behavior intention. Consumers use brand to create connection between their self concepts and brand image, this connection cause brand equity and long term consumer-brand relationship (Escalas \& Bettman, 2003). From the companies' point of view, brand is an efficient way for companies to distinguish their selves from competitors and enhance the marketing effectiveness (Sung \& Kim, 2010). Additionally, brand related outcomes such as market share and relative prices help them to differentiate their selves from their competitors and provide them competition advantages (Keller, 1993). It means that; brands which have high market share and acceptable relative price show a tendency to high levels of repurchase intention among their consumers (Ehrenberg et al.,2003).

Large stream of literature underlines the importance of brand trust and brand affect impact by creating brand loyalty (Iglesias et al.,2011). In the similar vein our results show that brand trust and brand affect play a critical role in forming brand loyalty. Both of these constructs have an impact on consumers' brand loyalty. Brand trust and brand affect conducts a certain marketing advantages such as reducing marketing cost, gaining more new consumers, providing great trade leverage, performing favorable word of mouth and resisting among competitors marketing efforts. Therefore if marketing managers want to maintain continuity of both of these constructs, they can justify promotion expenditures. Moreover they can concentrate on their communication and merchandising strategy to create long term effects on their consumers to preserve brand trust, brand affect and brand loyalty. All of these critical constructs contribute to generate profitable brand outcomes.

It is essential to understand that brand trust and brand affect is generated through consumers' experiences with brand. Consumers do not form any subjective perceptions about brands before consuming them. Therefore companies should focus on creating unique experiences between their consumers and brands. Companies can induce consumer experience with brands through the appropriate coordination of marketing communication elements such as advertising, price, packaging, symbols, logos, slogans, store location.

Further researches should take into consideration of different product category characteristics (ie. hedonic, symbolic and utilitarian products) influence on brand loyalty. Moreover to generalize our findings; future researches would be focus on different product categories, services and brands such as luxury goods, hotels etc. Finally, the main limit of this study is using convenience sample of graduate and undergraduate students which prevents to generalize the findings. Therefore, future researches are needed to enhance sample size via covering other age groups. 


\section{Appendix A- Constructs and measurement items}

\begin{tabular}{|c|c|c|c|}
\hline Constructs & Label & Items & Operationalization \\
\hline \multirow[t]{4}{*}{ Brand Trust } & $\overline{\mathrm{Bt} 1}$ & I trust this brand & \multirow{4}{*}{$\begin{array}{l}\text { Extremely disagree (1) } \\
\text { - extremely agree }(5)\end{array}$} \\
\hline & $\mathrm{Bt} 2$ & I feel that I can trust this brand completely & \\
\hline & $\mathrm{Bt} 3$ & I cannot rely on this brand $\AA$ & \\
\hline & Bt4 & $\begin{array}{l}\text { I feel secure when I buy this brand because I } \\
\text { know that it will never let me down }\end{array}$ & \\
\hline \multirow[t]{7}{*}{ Brand Affect } & $\mathrm{Ba} 1$ & This coffee store makes me feel happy. & \multirow{7}{*}{$\begin{array}{l}\text { Extremely disagree }(1) \\
\text { - extremely agree (5) }\end{array}$} \\
\hline & $\mathrm{Ba} 2$ & This coffee store makes me feel pleased. & \\
\hline & $\mathrm{Ba} 3$ & This coffee store makes me feel entertained. & \\
\hline & $\mathrm{Ba} 4$ & This coffee store makes me feel arouse. & \\
\hline & $\mathrm{Ba} 5$ & This coffee store makes me feel peace. & \\
\hline & $\mathrm{Ba} 6$ & This coffee store makes me feel love. & \\
\hline & $\mathrm{Ba} 7$ & This coffee store makes me feel relief. & \\
\hline \multirow[t]{3}{*}{$\begin{array}{l}\text { Brand } \\
\text { alty }\end{array}$} & Bl1 & $\begin{array}{l}\text { I use this coffee store whenever I go to a coffee } \\
\text { shop. }\end{array}$ & \multirow{3}{*}{$\begin{array}{l}\text { Extremely disagree }(1) \\
\text { - extremely agree }(5)\end{array}$} \\
\hline & $\mathrm{B} 12$ & $\begin{array}{l}\text { I would strongly recommend this coffee store to } \\
\text { anyone. }\end{array}$ & \\
\hline & $\mathrm{B} 13$ & $\begin{array}{l}\text { I would like to come back to this coffee store in } \\
\text { the future. }\end{array}$ & \\
\hline
\end{tabular}




\section{REFERENCES}

Anderson, J.C. and Gerbing, D.W. (1988) Structural equation modeling in practice: a review and recommended two-step approach. Psychological Bulletin, 103, 411-423.

Berry, L. L. (1983). Relationship marketing. In L. T. Berry, G. L. Shostack, \& G. D. Upah (Eds.), Emerging perspectives on service marketing (pp. 25-28). Chicago: American Marketing Association.

Berry, L. L. and. Parasuraman, A.A. (1991). Marketing Services: Competing Through Quality. New York, NY: Free Press.

Caceres, R. C. and Paparoidamis, N. G. (2007). Service quality, relationship satisfaction, trust, commitment and business-to-business loyalty. European Journal of Marketing, 41(7/8), 836-867.

Casalo, L. V., Flavian, C. and Guinaliu, M. (2007). The influence of satisfaction, perceived reputation and trust on a consumer's commitment to a website. Journal of Marketing Communications, 13, 1-17.

Chaudhuri, A. and Holbrook, M.B. (2001). The chain of effects from brand trust and brand affect to brand performance: The role of brand loyalty. Journal of Marketing , 6 ,81-93.

Chiou, J. S. and Droge, C. (2006). Service quality, trust, specific asset investment, and expertise: Direct and indirect effects in a satisfaction-loyalty framework. Journal of the Academy of Marketing Science, 34(4), 613-627.

Delgado-Ballester, E. and Munuera-Alemán, J. L. (2001). Brand Trust in the Context of Consumer Loyalty. European Journal of Marketing, 35, 1238-1258.

Dick., A. S. and Basu, K. (1994). Customer Loyalty: Toward an Integrated Conceptual Framework. Journal of the Academy of Marketing Science, 22, 99-113.

Doney, P. M. and Cannon, J.P. (1997). An Examination of the Nature of Trust in Buyer-Seller Relationships. Journal of Marketing, 61, 35-51.

Escalas, J. E. and Bettman, J. R. (2003). You are what they eat: The influence of reference groups on consumers' connections to brands. Journal of Consumer Psychology, 13, 339-348.

Fornell, C. and Larcker, D.F. (1981). Evaluating structural equation models with unobservable variables and measurement error. Journal of Marketing Research, 18, 39-50.

Helmig, B.; Huber, J.A. and Leeflang , P. (2007). Explaining behavioural intentions toward cobranded products. Journal of Marketing Management, 23(3),.285-304.

Iglesias, O., Singh, J. J. amd Batista-Foguet, J.M. (2011). The role of brand experience and affective commitment in determining brand loyalty. Journal of Brand Management, 18 (8), 570-582.

Izard, C. (1977) Human Emotions. New York7 Plenum.

Jacoby, J. and Chestnut, R. (1978). Brand Loyalty Measurement and Management. New York: John Wiley \& Sons.

Keller, K.L. (1993). Conceptualizing, Measuring, and Managing Customer-Based Brand Equity. Journal of Marketing, 57, 1-22.

Lau, G.T. and Lee, S.H. (1999). Consumers' trust in a brand and the link to brand loyalty. Journal of Market Focused Management, 4, 341-370.

Mano, H. and Oliver, R.L. (1993) Assessing the dimensionality and structure of the consumption experience: evaluation, feeling, and satisfaction. Journal of Consumer Research, 20, 451-466.

Moorman, C., Zaltman,G. and Deshpande, R. (1992).Relationshtps Between Providers and Users of Market Research: The Dynamics of Trust Within and Between Organizations. Journal of Marketing Research, 29 , 314-28. 
Morgan, R. M., and Hunt, S. D. (1994). The commitment trust theory of relationship marketing. Journal of Marketing, 58(2), 20-38.

Nunally, J. (1978) Psychometric Theory, 2nd ed. McGraw-Hill, New York, NY.

Richins, M.L. (1997) Measuring emotions in the consumption experience. Journal of Consumer Research, 24, 127-146.

Spekman, R,E. (1988). Strategic supplier selection: Understanding long term buyer relationships. Business Horizons, 31 (4), 75-81.

Sung, Y. and Kim, J. (2010). Effects of Brand Personality on Brand Trust and Brand Affect. Psychology \& Marketing, 27(7), 639-661.

Tümer Kabadayı, E.; Koçak Alan, A. and Erdebil, A.E. (2011). The Factors Affecting The Level Of Trust Between Buyer Seller: An Example From Household Appliances Sector . Journal of Global Strategic Management,5 (1), 31-39.

Wu ,W-P, Chan, T. S. and Lau, H. H. (2008). Does consumers' personal reciprocity affect future purchase intentions. Journal Of Marketing Management, 24, 345-360.

Zeithaml, V.A., Berry, L.L. and Parasuraman, A. (1996) The behavioral consequences of service quality. Journal of Marketing, 60, 31-46. 